\title{
Radiation Genetics in Wheat, V. \\ Influence of Irradiation Time and Temperature on the \\ Genetic Effects of Ionizing Radiation in Diploid Wheat*
}

\author{
Seiji Matsumura \\ National Institute of Genetics, Misima
}

Received June 18, 1960

UDC : 633. $11: 539.167: 575.23$

Since temperature is known to affect many biological processes, this factor cannot be neglected. The influence of temperature on radiation-induced mutations has been repeatedly studied. A number of researchers agree that the number of chromosome aberrations is smaller if irradiation is conducted at higher temperature (Rick 1940 ; Sax 1947 ; Fabergé 1948). This is probably an effect on rejoining, but attempts to demonstrate it (Sax 1947) have not been successful, although a positive effect had been reported earlier (Sax \& Enzmann 1939). Fabergé also reported that temperature is effective during irradiation only and not if applied before or after treatment.

One part of the experiments reported in this paper have been undertaken in order to examine the question whether or not the temperature in seed storage after irradiation has an effect on the growth of seedlings and on inducing mutations.

Further, an influence of intensity on the effect of a radiation has been reported for numerous effects such as killing of bacteria. In all these cases sigmoid killing curves were obtained. This is in contrast to the effects previously obtained in experiments on mutations, where a direct proportionality between dose and mutation rate was always found, independently of the time factor. This difference between "physiological" radiation effects and mutation effects has been explained by the assumption of presence or absence of recovery.

Also it was well established that at high dosages the same number of $r$ units induces the same number of mutations whether it was applied at one (acute) irradiation or spread over a considerable time (chronic irradiation). But it has been recently reported that at low dosages this relationship is not always true (Russell 1958). In order to compare these physiological and genetic effects of acute and chronic irradiation, another series of experiments has been planned (cf. Matsumura 1959). 


\section{Materials and methods}

A variety of diploid wheat Triticum monococcum L. var. flavescnes Körn. was used in this study. The same materials have been mostly used as in the experiments of the previous reports of this series.

Dormant seeds were exposed to X-and $\gamma$-rays at the dosage of 10 and $20 \mathrm{kr}$ in September-October, 1956. Unfiltered X-ray irradiation was applied at $160 \mathrm{kVp}$, $3 \mathrm{~mA}$ tube current, $14 \mathrm{~cm}$ distance and $257 \mathrm{r} / \mathrm{min}$ intensity, by the Matsuda's type KXC-17 apparatus with the tube type STO $-200-3$. The dosages were measured by Siemens' Universal Dosimeter. For $\gamma$-ray irradiation the facility for cobalt 60 with 50 curies in our $\gamma$-ray room (Fujii \& Matsumura 1958; Kondo \& Matsumura 1958) was used. The measurements of $\gamma$-dosage were made with the use of a small CdS gamma meter made by Philips Co. Acute $\gamma$-irradiation was applied by ${ }^{63} \mathrm{Co}$ for 18 hours at intensity of $1,100 \mathrm{r} / \mathrm{hr}$ at $10 \mathrm{kr}$ and $2,200 \mathrm{r} / \mathrm{hr}$ at $20 \mathrm{kr}$. Dormant seeds were subjected for acute irradiation to both $\mathrm{X}$ - and $\gamma$-ray treatments either immediately before sowing or the irradiated seeds were kept for 30 days in storage. For chronic irradiation $\gamma$-ray treatment lasted 54 days at intensity of $200 \%$ day at $10 \mathrm{kr}$ and $400 \mathrm{r} /$ day at $20 \mathrm{kr}$.

To compare the genetic effects of $\beta$-radiation with those of $\mathrm{X}$ - and $\gamma$-radiations, 50 seeds were soaked in ${ }^{32} \mathrm{P}$ solutions of $2 \mathrm{cc}$ for one day at $0^{\circ} \mathrm{C}$ which contained 100 $\mu \mathrm{c} / \mathrm{cc}(\beta-10)$ and $200 \mu \mathrm{c} / \mathrm{cc}(\beta-20)$. The soaked seeds were washed and kept on moist filter paper in petri dishes for 17 hours in room temperature and then sown October 27 th, 1956.

\section{Effects upon the growth of seedlings and the fertility of $\mathrm{X}_{1}$ plants}

The germination rate of $\mathrm{X}$ - or $\gamma$-irradiated seeds and the growth of seedlings were compared for acute and chronic irradiation. In one experiment with acute irradiation one part of the irradiated seeds was kept at room temperature (aboit $20^{\circ} \mathrm{C}$ ) and the remainde: at low tempe ature $\left(5^{\circ} \mathrm{C}\right)$ for 30 days. Also, the effects of $\beta$-radiation by ${ }^{32} \mathrm{P}$ were examined for comparison.

The data are shown in Table 1 and Figure 1. There was no marked difference in germination rate between intreated and treated seeds at $10 \mathrm{kr}$, while the germination rate was rediced to $1 / 2-2 / 3$ at $20 \mathrm{kr}$.

$\mathrm{X}$ - and $\gamma$-irradated seeds were sown October 25th, 1956 and the length of seedlings was measured 12, 19 and 27 days after sowing. On the other hand, $\beta$-irradiated seeds, which were soaked in ${ }^{32} \mathrm{P}$ soluton, were sown October 27th, 1956 and the seedlings were measured 25 days after sowing. Acute X-irradiation applied just before sowing was more effective in inhibiting the growth of seedlings than when the seeds were kept after treatment 30 days in storage.

In the case of 30 day storage, $\gamma$-rays inhibited the seedling growth more than $\mathrm{X}$-rays, while irradiation applied just before sowing showed the reverse relation. It was further found, especially with $\gamma$-rays, that low temperature was more effective in 
Table 1. Effects of different ionizing irradiations on seedling growth and fertility in Triticum monococcum.

\begin{tabular}{|c|c|c|c|c|c|}
\hline \multirow[t]{2}{*}{ Treatment } & \multirow{2}{*}{$\begin{array}{l}\text { Dosage } \\
(\mathrm{kr})\end{array}$} & \multicolumn{3}{|c|}{$\begin{array}{l}\text { Seedlings length }(\mathrm{cm}) \\
\text { days after sowing }\end{array}$} & \multirow{2}{*}{$\begin{array}{l}\text { Fertility } \\
\text { of spikes } \\
\text { in } \mathrm{X}_{1}(\%)\end{array}$} \\
\hline & & 12 & 19 & 27 & \\
\hline Control & 0 & 11.19 & 15.51 & $\begin{array}{l}17.69 \\
(11.08) *\end{array}$ & 74.62 \\
\hline $\begin{array}{c}30 \text { day } \\
\text { storage } \\
\text { at room } \\
\text { temperature }\end{array}$ & $\begin{array}{r}\mathrm{X}-10 \\
\mathrm{X}-20 \\
\gamma-10 \\
\gamma-20\end{array}$ & $\begin{array}{l}9.96 \\
8.69 \\
4.21 \\
2.67\end{array}$ & $\begin{array}{r}12.47 \\
12.53 \\
5.75 \\
4.71\end{array}$ & $\begin{array}{r}14.99 \\
13.53 \\
8.96 \\
6.79\end{array}$ & $\begin{array}{l}81.82 \\
11.59 \\
60.32 \\
32.78\end{array}$ \\
\hline $\begin{array}{r}30 \text { day } \\
\text { storage } \\
\text { at } 5^{\circ} \mathrm{C}\end{array}$ & {$\left[\begin{array}{r}\mathrm{X}-10 \\
\mathrm{X}-20 \\
\gamma-10 \\
\gamma-20\end{array}\right.$} & $\begin{array}{l}8.95 \\
4.55 \\
4.16 \\
1.04\end{array}$ & $\begin{array}{r}12.14 \\
8.11 \\
7.34 \\
2.01\end{array}$ & $\begin{array}{r}13.81 \\
11.63 \\
9.73 \\
3.45\end{array}$ & $\begin{array}{r}61.95 \\
33.53 \\
60.58 \\
8.34\end{array}$ \\
\hline $\begin{array}{c}\text { Acute } \\
\text { irradiation } \\
\text { just before } \\
\text { sowing }\end{array}$ & $\begin{array}{r}\mathrm{X}-10 \\
\mathrm{X}-20 \\
\gamma-10 \\
\gamma-20\end{array}$ & $\begin{array}{l}4.90 \\
2.39 \\
7.29 \\
3.12\end{array}$ & $\begin{array}{l}6.99 \\
3.72 \\
8.80 \\
5.32\end{array}$ & $\begin{array}{r}10.71 \\
4.29 \\
12.00 \\
6.75\end{array}$ & $\begin{array}{l}62.32 \\
34.65 \\
64.38 \\
40.10\end{array}$ \\
\hline $\begin{array}{l}\text { Chronic } \\
\text { irradiation }\end{array}$ & $\begin{array}{l}\gamma-10 \\
\gamma-20\end{array}$ & $\begin{array}{l}8.48 \\
1.98\end{array}$ & $\begin{array}{r}12.65 \\
3.29\end{array}$ & $\begin{array}{r}14.69 \\
5.37\end{array}$ & $\begin{array}{l}66.45 \\
15.47\end{array}$ \\
\hline${ }^{32} \mathrm{P}$ & $\begin{array}{l}\beta-10 \\
\beta-20\end{array}$ & & & $\left\{\begin{array}{l}12.66) * \\
14.14)^{*}\end{array}\right.$ & $\begin{array}{l}68.60 \\
79.28\end{array}$ \\
\hline
\end{tabular}

* X- and $\gamma$-irradiated seeds were sown October 25 th, 1956.

( ) Sown October 27 th and measured 25 days after sowing.

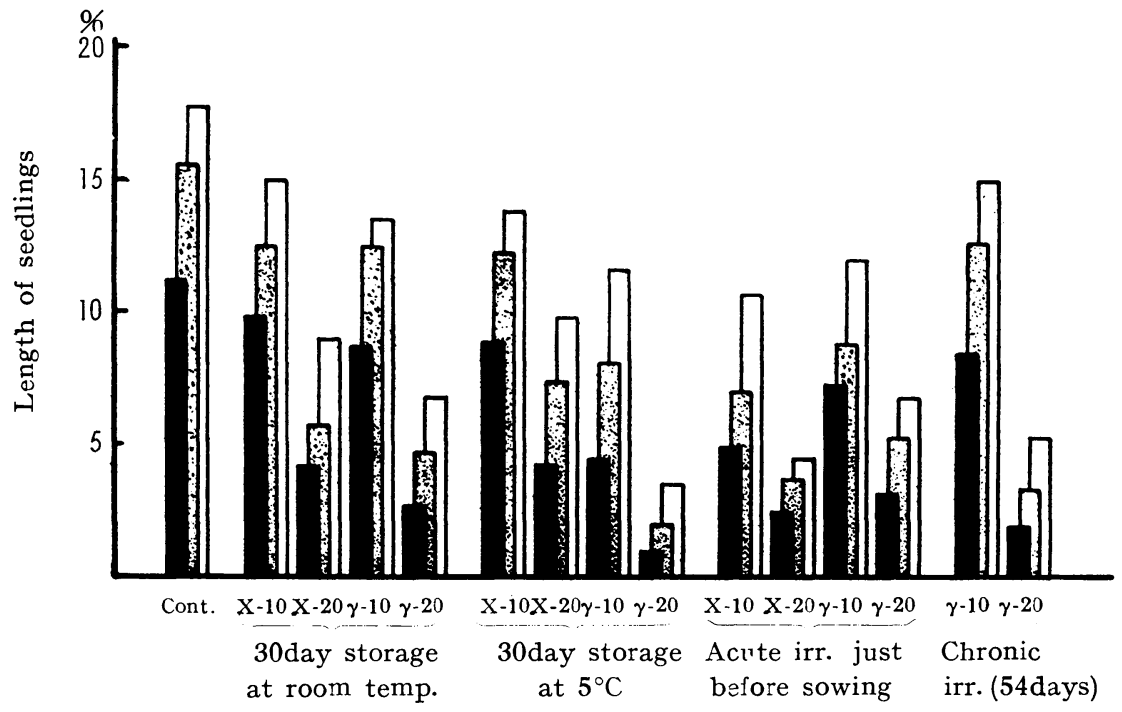

Fig. 1. Effects of temperature and irradiation time upon growth of seedings after irradiation. Length of seedings was measured 12(black), 19 (stippled) and 27 (white) days after sowing.

inhibiting growth than room temperature. At $10 \mathrm{kr}$, acute $\gamma$-irradiation was more effective in this respect than the chronic one. On the other hand, at $20 \mathrm{kr}$ the reverse relation between acute and chronic $\gamma$-irradiation was observed. Also, the effect of 
$\beta$-radiation on the growth of seedlings was unexpectedly slight (cf. Matsumura \& Fujii 1957 ; Matsumura, Fujii \& Kondo 1957).

Figure 2 shows the relation between induced sterility of $\mathrm{X}_{1}$ plants and radiation

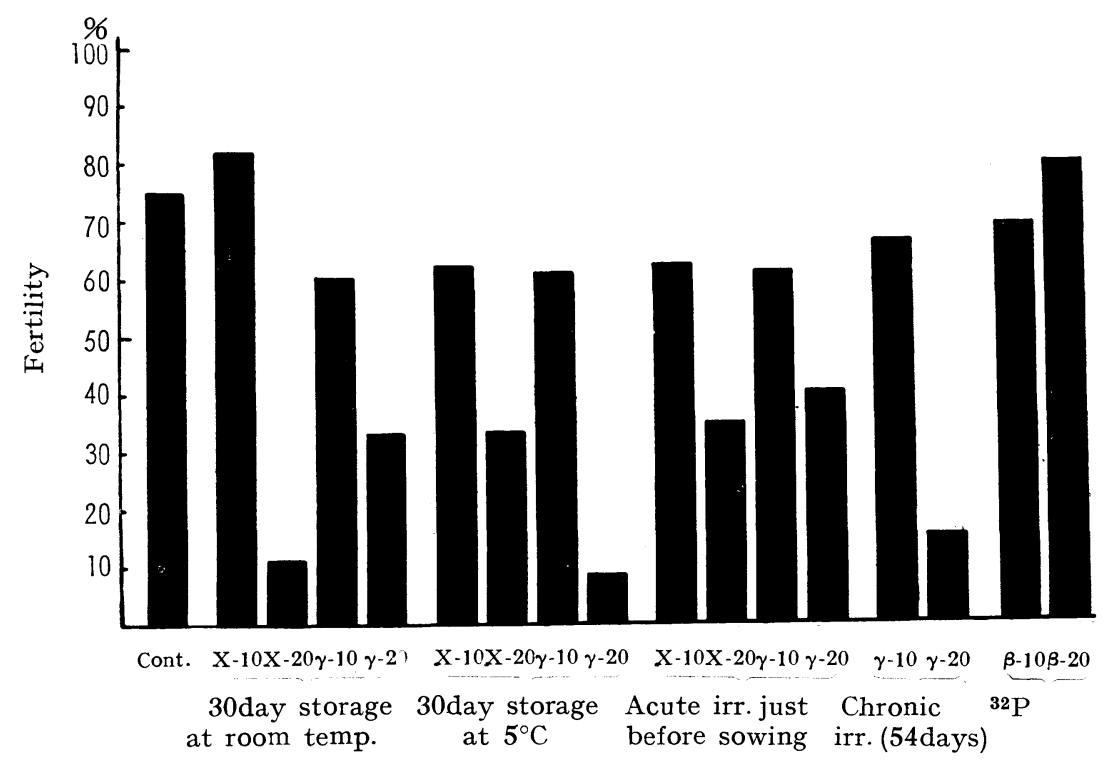

Fig. 2. Relation between induced sterility in $\mathrm{X}_{1}$ plants and radiation dosage, temperature in storage and irradiation time (1957).

dosage, temperature in storage and irradiation time. It coincides roughly with the relation between the inhibition of seedling growth and all those conditions.

\section{Effects on chromosome aberrations in $\mathrm{X}_{1}$}

The frequency of spikes with induced chromosome aberrrations in $\mathrm{X}_{1}$ plants was strikingly higher at $20 \mathrm{kr}$ than at $10 \mathrm{kr}$. The most frequent aberrations were (4) $+5 \mathrm{II}$, often $6 \mathrm{II}+2 \mathrm{I}$, (6) $+4 \mathrm{II}$, (4) +(4) $+3 \mathrm{II}$ or (4) $+4 \mathrm{II}+2 \mathrm{I}$ were observed and $1 \mathrm{III}+5 \mathrm{II}+1 \mathrm{I}$ or asynaptic 14I were seldom seen. The data are shown in Table 2.

The effect of $\gamma$-rays was generally stronger than that of X-rays. In the case of 30 day storage, $10 \mathrm{kr} \mathrm{X}$-rays showed no effects. But at $20 \mathrm{kr}$ storage at low temperature was more effective for $\mathrm{X}$-rays than for $\gamma$-rays, as an exception.

Also, irradiation just before sowing and 30 day storage at low temperature produced, in general, more chromssome aberrations than storage at room temperature after irradiation. On the other hand, the effect of chronic $\gamma$-irradiation was less. Also, the effect of $\beta$-radiation was very slight, as expected from the effects on the growth of seedlings and fertility of $\mathrm{X}_{1}$ plants (cf. Matsumura 1958).

\section{Effects on induced mutations in $\mathbf{X}_{2}$}

The frequency in $\mathrm{X}_{2}$ of head progenies with induced mutations increased with the increase of radiation dosage, as shown in Table 3 . Because of the small number of 
Table 2. Effects of different ionizing irradiations on chromosome aberrations in $\mathrm{X}_{1}$ of Triticum monococcum.

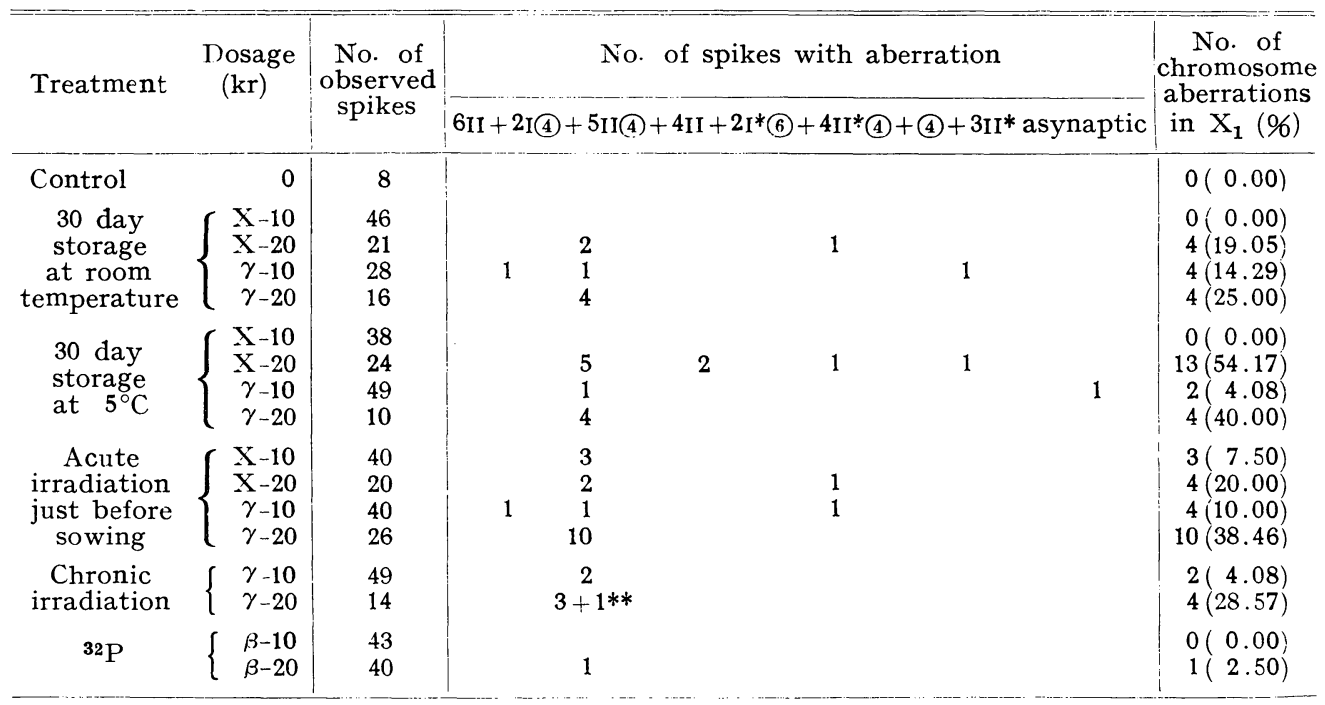

* Counted as two aberrations.

$* * 1 I I I+5 I I+1 I$.

Table 3. Effects of different ionizing irradiations on gene mutations in $\mathrm{X}_{2}$ of Triticum monococcum.

\begin{tabular}{|c|c|c|c|c|c|c|c|c|}
\hline \multirow{2}{*}{ Treatment } & \multirow{2}{*}{$\begin{array}{l}\text { Dosage } \\
(\mathrm{kr})\end{array}$} & \multirow{2}{*}{$\begin{array}{c}\text { No. of } \\
\text { observed } \\
\text { head } \\
\text { progenies }\end{array}$} & \multicolumn{4}{|c|}{$\begin{array}{c}\text { No. of head } \\
\text { progenies with mutants or haploids }\end{array}$} & \multirow{2}{*}{\begin{tabular}{|} 
No. of \\
gene \\
mutations \\
in $\mathrm{X}_{2}$ \\
$(\%)$
\end{tabular}} & \multirow{2}{*}{\begin{tabular}{|} 
No. of \\
head \\
progenies \\
without \\
germination \\
$(\%)$
\end{tabular}} \\
\hline & & & albina & $\begin{array}{l}\text { other chlo- } \\
\text { rophyll } \\
\text { mutants }\end{array}$ & $\begin{array}{l}\text { remaining } \\
\text { mutants }\end{array}$ & haploid & & \\
\hline Control & 0 & - & & & & & $0(0.0)$ & $0(0.0)$ \\
\hline $\begin{array}{c}30 \text { day } \\
\text { storage } \\
\text { at room } \\
\text { temperature }\end{array}$ & $\left\{\begin{array}{r}\mathrm{X}-10 \\
\mathrm{X}-20 \\
\gamma-10 \\
\gamma-20\end{array}\right.$ & $\begin{array}{r}64 \\
8 \\
45 \\
13\end{array}$ & & $\begin{array}{l}1 \\
1\end{array}$ & $\begin{array}{l}1 \\
1\end{array}$ & $\begin{array}{l}1 \\
1\end{array}$ & $\begin{array}{l}0(0.0) \\
1(16.7) \\
2(5.7) \\
1(11.1)\end{array}$ & $\begin{array}{r}12(18.8) \\
2(25.0) \\
10(22.2) \\
4(30.8)\end{array}$ \\
\hline $\begin{array}{l}30 \text { day } \\
\text { storage } \\
\text { at } 5^{\circ} \mathrm{C}\end{array}$ & $\left\{\begin{array}{r}X-10 \\
X-20 \\
\gamma-10 \\
\gamma-20\end{array}\right.$ & $\begin{array}{r}58 \\
11 \\
68 \\
3\end{array}$ & $\begin{array}{l}1 \\
3 \\
1\end{array}$ & 1 & 1 & 8 & $\begin{array}{l}1(2.3) \\
1(14.3) \\
6(9.1) \\
1(33.3)\end{array}$ & $\begin{array}{r}14(24.1) \\
4(36.4) \\
2(2.9) \\
0(0.0)\end{array}$ \\
\hline $\begin{array}{c}\text { Acute } \\
\text { irradiaton } \\
\text { just before } \\
\text { sowing }\end{array}$ & $\left\{\begin{array}{c}X-10 \\
X-20 \\
\gamma-10 \\
\gamma-20\end{array}\right.$ & $\begin{array}{l}51 \\
21 \\
52 \\
30\end{array}$ & 1 & $\begin{array}{l}2 \\
2 \\
1\end{array}$ & 1 & $\begin{array}{l}2 \\
2\end{array}$ & $\begin{array}{l}3(6.1) \\
2(13.3) \\
2(5.3) \\
1(5.6)\end{array}$ & $\begin{array}{r}2(3.9) \\
6(28.6) \\
14(26.9) \\
12(40.0)\end{array}$ \\
\hline $\begin{array}{l}\text { Chronic } \\
\text { irradiation }\end{array}$ & $\begin{array}{l}\gamma-10 \\
\gamma-20\end{array}$ & $\begin{array}{r}69 \\
5\end{array}$ & & 3 & 2 & 1 & $\begin{array}{l}3(5.3) \\
2(50.0)\end{array}$ & $\begin{array}{r}12(17.4) \\
1(20.0)\end{array}$ \\
\hline${ }^{32} \mathrm{P}$ & $\left\{\begin{array}{l}\beta-10 \\
\beta-20\end{array}\right.$ & $\begin{array}{l}69 \\
81\end{array}$ & $\begin{array}{l}1 \\
1\end{array}$ & 2 & & $\begin{array}{l}1 \\
3\end{array}$ & $\begin{array}{l}1(1.9) \\
3(4.1)\end{array}$ & $\begin{array}{r}17(24.6) \\
8(9.9)\end{array}$ \\
\hline
\end{tabular}

observed head progenies, due to a lower survival rate, the results with $20 \mathrm{kr}$ irradiation were not conclusive. Acute $\gamma$-irradiation at $20 \mathrm{kr}$ just before sowing had unexpectedly only a slight effect, but showed the highest frequency of non-germinating head progenies. The results were roughly in accord with the observations of chromosome 
aberrations.

About $80 \%$ of mutants were chlorophyll abnormalities, of which about $40 \%$ were albina and the remaining xantha, chlorina, viridis, virido-albina, basi-viridis, striata and so on. The other mutants were: dwarf, short culm, short awned, bent leaf, sterile, etc.

Table 4 shows the relationship between the fertility of single spikes in $\mathrm{X}_{1}$ and the frequency of head progenies with induced mutations. There was no correlation.

Table 4. Relation between single spike fertility in $\mathrm{X}_{1}$ and head progenies with mutants or haploids in $\mathrm{X}_{2}$.

\begin{tabular}{|c|c|c|c|c|c|c|c|c|c|c|c|}
\hline Fertility (\%) & $\begin{array}{c}0 \\
1 \\
10\end{array}$ & $\begin{array}{c}11 \\
1 \\
20\end{array}$ & $\begin{array}{c}21 \\
1 \\
30\end{array}$ & $\stackrel{31}{1}$ & $\stackrel{41}{1}$ & $\begin{array}{c}51 \\
1 \\
60\end{array}$ & $\begin{array}{c}61 \\
1 \\
70\end{array}$ & $\begin{array}{c}71 \\
1 \\
80\end{array}$ & $\begin{array}{c}81 \\
1 \\
90\end{array}$ & $\begin{array}{l}91 \\
1 \\
100\end{array}$ & Total \\
\hline No. of spikes & 83 & 36 & 36 & 63 & 73 & 65 & 63 & 96 & 143 & 122 & 780 \\
\hline Albina & & & & 1 & 1 & 2 & 1 & & 2 & 2 & 9 \\
\hline $\begin{array}{l}\text { Other chlo- } \\
\text { rophyll } \\
\text { mutants }\end{array}$ & & & 1 & 5 & & & & 1 & 6 & 2 & 15 \\
\hline $\begin{array}{l}\text { Remaining } \\
\text { mutants }\end{array}$ & & 1 & & 1 & & & 1 & 3 & 1 & & 7 \\
\hline Haploids & & & & 1 & & 1 & 3 & 5 & 5 & 6 & 21 \\
\hline $\begin{array}{c}\text { Total } \\
\text { (Except } \\
\text { haploids) }\end{array}$ & & 1 & 1 & 7 & 1 & 2 & 2 & 4 & 9 & 4 & 31 \\
\hline
\end{tabular}

Moreover, in $21(c a .3 \%)$ of all $780 \mathrm{X}_{2}$ head progenies 1 or 2 haploid plants were observed. The frequency of head progenies with haploids seemed to be not due to the kind of irradiation ; neither was it connected with the fertility of $\mathrm{X}_{1}$ spikes, but depended on the radiation dosage.

\section{Discussion}

The question whether or not post-irradiation environment in which biological systems are maintained can modify the ultimate extent of irradiation injury has been of concern to radiobiologists for a number of years. The problem was of particular interest to radiation geneticists because of the indication that some post-treatments might modify the ratio of mutations to chromosome aberrations that can be detected after a given dose of X-rays (Caldecott \& Smith 1952 ; Adams, Nilan \& Gunthart 1955 ; Adams \& Nilan 1958). With these earlier works in mind a series of experiments was initiated in order to expand and confirm the studies conducted by Curtis et al. (Caldecott 1959). A number of tests showed that seedling injury due to $\mathrm{X}$-irradiation increased as a function of the duration of seed storage. On the other hand, there might be a very slight increase in injury with fast and thermal neutrons as a function of duration but it was not of the same order of magnitude as that obtained with X-rays. Also, Ehrenberg (1955) reported that the stograge for 2 weeks at room temperature after irradiation was found to increase the damage of seedling growth with $\mathrm{X}$-rays, 
but not when fast neutrons were used. The storage effect was relatively greater when the seeds were stored at abo at $25^{\circ} \mathrm{C}$ than when the temperature was about $12^{\circ} \mathrm{C}$.

In our experiments the reverse relation was observed with X-rays. Namely acute irradiation just before sowing was more effective in injuring the seedlings than when storage after irradiation was used. On the other hand, the effect of $\gamma$-irradiation applied just before sowing was intermediate between low and high temperature storage following irradiation. Thus a recovery from radiation damage due to storage was found, especially at high temperature. Such recovery phenomenon was striking at chronic irradiation, in comparison with the acute treatment.

Also, as to chromosome aberrations and gene mutations, low temperature storage or acute irradiation was generally somewhat more effective than high temperature storage or chronic irradiation. King (1947) reported that low temperature treatment $\left(0.5^{\circ} \mathrm{C}\right)$ during irradiation increased the gene mutation rate in Drosophila, compared with room temperature, and similar results concerning chromosome aberrations reported by Rick (1940) and Fabergé (1948) were already mentioned in the beginning of this paper.

There were no relationships between the fertility of single spikes in $X_{1}$ and the frequency of $\mathrm{X}_{2}$ head progenies with induced mutations. Similar results were already reported for barley by Yamaguchi (1958) and Gaul (1959)

Haploid plants seem to have been induced in some of $\mathrm{X}_{2}$ head progenies. In Triticum monococcum var. vulgare spontaneous occurrence of haploids was often reported (Kihara 1940), but was not yet for var. flavescens. As to the cause of induction of haploids in the $\mathrm{X}_{2}$ generation, further investigations must be carried out.

The effects of $\beta$-irradiation by ${ }^{32} \mathrm{P}$ solution were unexpectedly slight. It was found from another experiment with seed absorption of ${ }^{32} \mathrm{P}$ solution by Kondo et al. (1958) that the actual dosage of $\beta$-rays was very low.

\section{Summary}

Dormant seeds of Triticum monococcum flavescens were exposed to $\mathrm{X}$ - and $\gamma$-rays at the dosage of 10 and $20 \mathrm{kr}$. Growth of seedlings, single spike fertility and chromosome aberrations of $\mathrm{X}_{1}$ plant and gene mutations in $\mathrm{X}_{2}$ were compared for acute and chronic irradiation. At acute irradiation with $\mathrm{X}$ - and $\gamma$-rays treatment was given either immediately before sowing or the irradiated seeds were kept for 30 days in storage at room temperature (about $20^{\circ} \mathrm{C}$ ) or at $5^{\circ} \mathrm{C}$. Also, the effect of $\beta$-radiation by ${ }^{32} \mathrm{P}$ was examined for comparison.

The relation between the inhibition of seedling growth and dosage, temperature in storage and irradiation time coincides roughly with the relation between the percentage of induced sterility and all those conditions. $\mathrm{X}$ - and $\gamma$-irradiations were far more effective at $20 \mathrm{kr}$ than at $10 \mathrm{kr}$. In the case of 30 day storage, $\gamma$-rays inhibited the growth of seedlings and reduced the fertility stronger than X-rays, while irradiation applied just before sowing showed the reverse relation. It was further observed, especially with $\gamma$-rays, that low temperature had the strongest inhibitory 
effect. At $10 \mathrm{kr}$ acute $\gamma$-irradiation was more effective than the chronic one, while at $20 \mathrm{kr}$ the reverse relation was observed.

The frequency of chromosome aberrations and gene mutations was strikingly higher at $20 \mathrm{kr}$ than at $10 \mathrm{kr}$. Irradiation just before sowing and 30 day storage at low temperature were more effective than storage at room temperature after irradiation. The effect of $\gamma$-irradiation was less.

The effects of $\beta$-irradiation were unexpectedly slight. It was found from another experiment with seed absorption of ${ }^{32} \mathrm{P}$ solution that the actual dosage of $\beta$-rays was very low.

Acknowledgements. The writer begs to express his indebtendness to Dr. Sohei Kondo and Mr. Taro Fujii of the National Institute of Genetics for their faithful help with the experiments.

The present study was partly supported by grants from the Scientific Research Fund of Ministry of Education.

\section{Literature cited}

Adams, J. D. and Nilan, R. A. 1958. After effects of ionizing radiation in barley. II. Rad. Res. 8: 111-122.

-__- _- and Gunthardt, H. 1955. Idem. I. Northwest Science 29: 101-108.

Caldecott, R. S. 1959. The experimental control of the mutation process. Ist Internatl. Wheat Genet. Symp. Winnipeg (1958) : 68-88.

and Smith, L. 1952. The influence of heat treatments on the injury and cytogenetic effects of X-rays on barley. Genetics 37 : 136-157.

Ehrenberg, L. 1955. The influence of post-radiation factors on effects produced in barley. Bacq \& Alexander (Ed.) : Radiobiology Symp., 1954 (Liège) : 285-289.

Fabergé, A. C. 1948. Action of temperature during X-ray treatment of Tradescantia chromosomes. Genetics 33: 104.

Fujii, T. and Matsumura, S. 1958. Radiosensitivity in plants. I. Jap. Jour. Genet. 33 : 389 397.

Gaul, H. 1958. Uber die gegenseitige Unabhängigkeit der Chromosomen und Punktmutationen. Zeit. Pflanzenz. 40 : 151-188.

Kihara, H. 1940. Formation of haploids by means of delayed pollination in Triticum monococcum. (Japanese). Bot. Mag. 54 : 178-185.

King, E. D. 1947. The effect of low temperature upon the frequency of X-ray induced mutations. Genetics 32: 161-164.

Kondo, S. and Matsumura, S. 1958. Dose-rate distribution in the ${ }^{60} \mathrm{Co} \gamma$-ray room. Ann. Rep. Natl. Inst. Genet. Japan No. 8 : 107-110.

-, Yokota, N. and Kawashima, S. 1958. Diffusion of radioisotopes in soaked wheat seeds. Ann. Rep. Natl. Inst. Crenet. Japan No. 8: 98-100.

Matsumura, S. 1958. Effects of temperature and irradiation time upon mutations induced by radiations. WIS, No. 7: 5-6. 1959. Radiation genetics in wheat. Ist Internatl. Wheat Genet. Symp. Winnipeg, (1958) : 112-133.

and Fujii, T. 1957. Genetic effects of ionizing radiation in Einkorn wheat. (Japanese). Proc. Ist. Symp. Atomic Energy No. 4 : 691-696. , - and Kondo, S. 1957. Effects of X- and gamma-radiations upon wheat seedling and their modification due to temperature or polyploidy. WIS, No. $6: 7-8$.

Rick, C. M. 1940. On the nature of X-ray induced deletions in Tradescantia chromosomes. Genetics 25 : 466-482.

Russell, W. L., Russell, L. B. and Kelly, E. M. 1958. Radiation dose rate and mutation frequency. Science 128 : $1546-1550$.

Sax, K. 1947. Temperature effects on X-ray induced chromosome aberrations. Genetics 33 : 104.

and Enzmann, E. V. 1939. The effect of temperature on the frequency of X-ray induced chromosome aberrations. Proc. Natl. Acad. Sci. 25 : 397-405.

Yamaguchi, H. 1958. The effect of fractional X-ray dosage on sterility and mutation in dormant seeds of rice and barley. (Japanese). Jap. Jour. Breed. $7: 213-220$. 